\title{
The 1945 Turkish-Soviet Crisis
}

\section{Devising a Foundational Myth for Turkish Foreign Policy}

\section{Behlül Özkan}

\author{
Behlül Özkan \\ Marmara University, Istanbul, Turkey \\ Faculty of Political Sciences \\ Department of International Relations \\ Associate Professor
}

ORCID: 0000-0002-3539-5319

E-mail: ozkanbehlul@gmail.com

Address: Marmara Universitesi Anadoluhisarı Kampusu

Siyasal Bilgiler Fakültesi

Kat 20 fis 214

Beykoz Istanbul, Turkey

DOI: $10.31278 / 1810-6374-2020-18-2-156-187$

\begin{abstract}
One of the key motifs of the Cold War was the assertion that in 1945 the USSR was "threatening" Turkey's territorial integrity by "demands" for the Turkish territories of Kars and Ardahan, and for military bases on the Straits. Those Soviet "demands" have served as a foundational myth for Turkey's foreign and domestic policy since 1945 . The main aim of the present article is to show that the USSR had no claims to Turkish territory or military bases and that those were merely proposals made in the context of Ankara's 1945 offer to the USSR regarding an alliance. However, by characterizing these proposals as "demands" the İnönü government was able to invent the myth of the Soviet "threat." It was used in foreign policy to precipitate Turkey's emergence from its WWII-era isolation (by integrating with the West right at the start of the
\end{abstract}


Cold War), and in domestic policy, to help the government build a political opposition as the country was transitioning to a multiparty political system.

Keywords: Turkey's foreign policy, early Cold War, the Straits issue, anticommunism, İsmet İnönü, Joseph Stalin

he crisis in Turkey's relations with the USSR immediately after
World War II profoundly influenced its post-1945 foreign and
domestic policy. There is a broad consensus among politicians, researchers and journalists writing about Turkey's foreign policy that the USSR became the number one "threat" to Turkey after 1945. According to this argument, Moscow threatened Turkey's territorial integrity by "claiming" the region encompassing Kars and Ardahan, as well as military bases on the Straits. Those making this claim hold that Turkey's adopting a pro-Western foreign policy was inevitable in conditions of the "threat" from the USSR after 1945. William Hale (2000, pp.111-12), the author of one of the most comprehensive studies of Turkish foreign policy, provided an account of the June 7, 1945 meeting between Soviet Foreign Minister Molotov and Turkey's ambassador to the USSR, Selim Sarper. According to Hale, Molotov-in return for the renewal of the expired 1925 Friendship Treaty between the two countries-demanded a "free passage of Soviet warships through the Straits and their closure to non-Black Sea states, the establishment of Soviet bases at the straits, and the retrocession to Russia of the eastern provinces of Kars and Ardahan which had been returned to Turkey in 1921."

Namik Kemal Zeybek, a prominent Turkish right-wing politician and thinker, argues that the "fear of communism" and anti-Communist attitudes make up the underlying "ideological texture" of Turkish society. Zeybek writes: "He [Stalin] directly threatened Turkey. It is a fact that he demanded bases on the Straits, that he demanded Kars and Ardahan... Turks became afraid that Stalin would subsequently take over Turkey using military force. Were their fears misplaced? No. Many individuals based their ideological framework, their ideological texture, on this legitimate fear" (Çakır and Göktaş, 1991, p.182). 
In 1971, journalist Metin Toker (1971), the son-in-law of İsmet İnönü (who, while serving as president from 1938 to 1950, was instrumental in crafting Turkish foreign policy) penned a series of articles in successive issues of the newspaper Milliyet, laying out the official line of the Soviet "threat," which had already become a foundational myth in Turkey's foreign policy. Remarkably, these articles were entitled Turkey's 1945 Nightmare. Stating that "the Russians are demanding territory and bases" in Turkey, Toker argued that Ankara's only legitimate hope of salvation was to come to its senses and join the Western camp. In Toker's view, the USSR's demands for "territory and bases" were merely a more palpable aspect of this "danger"; the USSR's true goal was to establish a pro-Soviet government in Turkey: "At stake was the security of the USSR. In the event that a 'more representative,' 'more democratic' government should be set up in Ankara, the Russian government would adopt a friendlier and more dependable stance towards it."

Since the end of the 1970s academic studies have called into question this foundational myth of the Soviet "demands." One of the most prominent of them, a study by Yalçın Küçük (1984, p.280), disputes the notion of the post-1945 "Soviet threat" to Turkey, arguing that this was merely a "fairy tale" invented by Ankara. According to Küçük, the İnönü government created the "Soviet threat" in order to achieve its aim of joining the Western camp; there were no Soviet "demands" for territory or bases. A similar statement by retired diplomat Mahmut Dikerdem (1989, p.89) that "no documents exist proving that the Soviets made formal demands of bases and territory from Turkey" raised a considerable outcry among scholars and retired diplomats upholding the official state-sponsored version of the events. Dikerdem commented on the reactions to his statement as follows: "There was such a firm belief in the truth of 'official history', society had been conditioned to such an extent against the Soviet threat, that expressing a contrary point of view was virtually considered a crime." Notably, in a column for Milliyet about a decade earlier, Dikerdem (1980) had written: "The powers governing Turkey have always tried to make sure that the country's destiny was tied up with the West. To this end, they have always taken great pains to keep the 'Soviet danger' and 
the 'Soviet threat' alive in the public eye." Taking the same line, Melvyn P. Leffler (1985) points out that the USSR made no "official demands" to Turkey in 1945, and that, contrary to the claims of traditional Cold War historians, the Kremlin's approach to Turkey was predominantly "defensive" rather than "expansionist."

The basic contention of this article is that the Soviets never "demanded" any territory or military bases from Turkey in 1945. In June of that year, there were two talks between Soviet Foreign Minister Molotov and Turkey's ambassador to the USSR, Selim Sarper. In response to Turkey's offer of an alliance with the USSR Molotov "proposed" making some changes to the Soviet-Turkish border and establishing military bases on the Straits, as a condition of the alliance. At various international meetings and summits Soviet politicians, like Stalin and Molotov, as well as American and British politicians and diplomats, constantly reiterated that Moscow made not "demands" but "proposals" in response to Turkey's offer of an "alliance." And yet, despite the fact that the İnönü government admitted as much in its own internal communications, it nonetheless promulgated the myth - both in statements to the public and in diplomatic settingsthat the USSR had threatened Turkey by "demanding" territory and military bases from Ankara. The notion that a Soviet threat to Turkey from 1945 onwards was an incontrovertible fact and that Turkey-in order to counter this threat-had no choice but to ally with the West in its foreign policy, is one which this article rejects. On the contrary, Turkey devised this Soviet "threat" for the very purpose of achieving rapprochement with the West. The underlying research question posed by this article is this: How did the İnönü government, from 1945 onwards, developed the myth that the USSR had "demanded" territory and military bases from Turkey in order for Turkey to 1) overcome its foreign-policy isolation and build an alliance with the West, and 2) manufacture its own political opposition and control the domestic political climate in its transition to a multi-party system (which was seen as a precondition for such an alliance)? Two important developments played a part in the creation of the Soviet "threat." First, the İnönü government had become isolated on the international arena 
due to its friendly relations with Nazi Germany during the Second World War; by devising a Soviet "threat" it therefore could re-establish close ties with the West. Second, in Turkey's transition to a multi-party system the Inönü government faced the danger of a broad domestic opposition in the form of a democratic front; by purging leftist and socialist-leaning politicians, academics and journalists (specifically, by using the pretext of the "communist danger"), the government ensured that the opposition would remain under its control. For the purposes of this article, the independent variables are Turkey's alliance with the West and the making of a domestic opposition which would not pose a danger to the regime. The dependent variable is the creation of a Soviet "threat" and Soviet "demands."

In claiming that the 1945 Turkish-Soviet crisis was devised as a foreign policy myth, I presume that from the theoretical perspective myths are political phenomena that appeal primarily to emotions and, consequently, have more influence on societies than ideologies do. Also, since myths do not rely on objective, rational arguments, they are impossible to be falsified (Della Salla, 2010, pp.3-9). In the pre-modern era, myths belonged to the semantic world of religion; however, they did not disappear with the advent of secularization and modernization, but rather were coopted by state systems of power as effective tools for establishing dominance and control over societies (Zaiotti, 2011, pp.540546). States have used myths for various purposes: to intimidate, subdue and pacify societies; to increase people's loyalty to the state by imparting a sense of its grandness; and to fabricate a serious threat in order to ensure popular support for the ruling elite. In an era when myths are constructed and used by the systems of power they cannot-given their appeal to the emotions-be questioned scientifically or critically. Not being subjected to any kind of critical scrutiny, myths grant a kind of invincibility to the state. At the same time myths create a meaning and a sense of belonging to a society, serve as a common reference point, while also conferring legitimacy upon ruling elites (Bottici, 2007).

During the extremely chaotic and uncertain period in the wake of WWII, the 1945 Turkish-Soviet crisis served as an effective means for Turkish society to make sense of its current circumstances. 
This myth made it possible for Turkey to join the Western alliance unconditionally as soon as WWII was over; throughout the Cold War era, it fostered a collective identity and a common purpose for Turkey's society. Moreover, any new developments or new information could only be understood in the light of this same myth. The myth of the 1945 Turkish-Soviet crisis portrayed the Soviet Union as an enemy threatening Turkey's territorial integrity; forming a synthesis with anti-communist ideology, it also preempted any criticism of Turkey's foreign policy. In effect, this myth served as a lens or a magnifying glass (Bennett, 1980): any aspect of Turkey's foreign policy was to be examined and understood via this myth while the myth itself became invisible and ubiquitous, like when someone peering through a lens or a magnifying glass does not see the instrument used.

The creation of this Soviet "threat" was a key factor in the Turkish masses' embrace of a pro-Western foreign policy after WWII. At the same time, it functioned as a key mechanism for shaping the domestic policy and silencing the opposition. During the Cold War, various members of Turkey's leftist opposition were branded as pawns of the Soviets who "had designs on" the country's territorial integrity, and as fifth columnists of an international communist movement wishing to splinter the Turkish nation. Indeed, even İnönü, who in 1945 had used the Soviet "threat" to neutralize the oppositional front challenging his single-party rule, saw his strategy backfire twenty years later when the slogan used by the CHP in the 1965 elections, Ortanin Solu (The Left of Center), was lampooned by right-wing parties as Ortanin Solu, Moskova Yolu (The Left of Center Is the Road to Moscow). By subjecting the 1945 crisis to critical scrutiny-for example, with regard to the language used to describe it ("a fact," "He really did [demand territory and bases in Turkey]," "a nightmare") — this article examines the creation of the Communist "menace," which proved to be the key element in Turkey's Cold-War-era domestic and foreign policies.

\section{TURKISH-SOVIET RELATIONS BETWEEN THE WORLD WARS}

The USSR was the largest foreign supporter of the resistance movement which sprang up in Anatolia following the dissolution of the Ottoman 
Empire. In the introduction to the Treaty of Moscow, signed in March of 1921, the Ankara and Moscow governments proclaimed their support for "the brotherhood of peoples and their right to determine their own destiny," declaring that the two powers would "work together to oppose imperialism" (Soysal, 1965). And indeed, the USSR enjoyed an honorable place in Turkish foreign policy under Atatürk. On December 17, 1925, a day after the League of Nations gave Mosul to Iraq (ceding to the demands of Britain which had a mandate to rule that country), the Turkish-Soviet Treaty of Friendship and Neutrality was signed. So close were the ties between Turkey and the USSR that when Turkey joined the League of Nations in 1932, it felt compelled to declare in advance that it would not join any future anti-Soviet alliance which might be formed in accordance with Article 16 of the Covenant of the League of Nations. Ankara evidently viewed the USSR as a useful counterweight in its own relations with the West.

Turkey's non-aligned foreign policy strategy began to change with the approach of the war, with Turkey tending to favor Britain more and more. On May 12, 1939, a joint declaration was issued between Turkey and Britain which spelled the end of Ankara's long-held position of foreign-policy neutrality. This period also marked the beginning of uneasy relations between Turkey and the USSR. In fact, during the meetings held prior to the Montreux Convention, Moscow expressed its concern that Turkey, instead of partnering with the USSR, might seek to exploit tensions between London and Moscow or even hew closely to British policies. These snags in Turkish-Soviet relations became even more pronounced after the German-Soviet Non-Aggression Pact was signed in August of 1939, shortly before the outbreak of WWII. With Turkey still in an alliance with Britain and France and the USSR having signed a non-aggression pact with Germany, then Foreign Minister Şükrü Saraçoğlu traveled to Moscow in the last week of September 1939 in order to break the impasse in Turkish-Soviet relations. Initially planned to last ten days, Saraçoğlu's visit dragged on for an unprecedented 23 days with one meeting after another (Tan, 1939). Despite countless face-to-face talks with Stalin and Molotov, it proved impossible to smooth over the differences caused by Turkey's and 
the USSR's recent treaties through which they had taken on mutually incompatible international obligations. In reference to Saraçoğlu's insistent request for a treaty of alliance with the USSR, Stalin tellingly asked: "What is the use of this pact then? Nothing" (Hasanli, 2011, p.5). Entering different camps as a result of the war in Europe, the two countries soon became estranged from each other.

\section{TURKEY'S “CHAMELEON NEUTRALITY” DURING WWII}

The frostiness in the Turkish-Soviet relations which had begun with the Montreux Convention only worsened as the war continued. A special point of contention was Germany's signing of a Treaty of Friendship with Turkey, just four days before Germany's invasion of the USSR on June 22, 1941. Germany's victories on its Western front induced Ankara to alter its foreign policy and its stance on the Soviet Union. Selim Deringil has described Turkey's foreign policy during the war as that of "active neutrality" (Deringil, 1997, p.295). Yet a more apposite term would be Niyazi Berkes's (1997) concept of "chameleon neutrality." Between 1941 and 1943, a considerable number of top Ankara politicians and bureaucrats believed that Germany would win the war and that the USSR would be destroyed. Accordingly, despite Turkey's remaining officially neutral, it tended towards the side that was superior at any given stage of the war. Until 1944, for instance, Turkey continued to export chromium (which was essential for the military industry) to Germany; moreover, it turned a blind eye to the illegal passage of a number of German warships through the Straits (Önder, 2010, p.144).

Starting in 1944, as it became increasingly clear that Hitler's forces would be routed by the Red Army and that it was Nazi Germany that was destined to "end up in the cemetery," Turkey's foreign policy underwent a change once again. In April 1944, the sales of chromium to Germany were halted, and in August of the same year Turkey severed diplomatic relations with Germany. Despite all these steps, however, there was an unending crisis of confidence not only between Turkey and the USSR but also between Turkey and the Western powersBritain and the U.S. In 1944, with President İnönü in office, objections 
to Turkey's foreign policy also began to be raised from within. For example, Tevfik Rüştü Aras, who served as Turkey's foreign minister for thirteen years (1925-1938), proposed such a change of course in his June 1944 article written for the newspapers Tan and Vatan. "We ought to make our relations with Russia, our northern neighbor, as friendly as possible, to the extent that is feasible and prudent for us to do so," he wrote (Aras, 1945, pp.14-24).

Those in power took a dim view of Aras's writings, deriding him as an "idealist." In response, Aras wrote another article entitled "I Shall Speak More Frankly" which was published on June 26, 1944 in Tan. In this piece, Aras can be said to have predicted the Cold War between the Allied powers in the aftermath of WWII: "If the United States, Soviet Russia, and Britain cannot cooperate with each other, the world will not be able to enjoy even a brief moment of peace. And I hold that each and every state has a paramount duty to try, as best as it can, to forestall such a possibility. Turkey, too, may fulfill its responsibility in this matter and pay its debt to the Soviets-who have helped us in these calamitous times-in a timely and appropriate fashion, I hope that we will steer our current relations with the Soviets into a very close friendship or indeed an alliance" (Aras, 1945, pp.29-31).

The emergence of a bipolar world, Aras believed, would result in a tense climate in which it would be a great mistake for Turkey to be at odds with the USSR. Yet in his writings Aras also stressed the need for preserving close ties with the West. Aras's stance of keeping an equal distance from both poles in the Cold War did not stem from his political views as such. Rather, he thought it would be the most advantageous strategy for Turkey. Thus the claim made by Maurice Peterson, a Turkish deputy foreign minister, to the British ambassador to Turkey that Aras was "a well-known Soviet agent," is a telling indication of how unpopular Aras's ideas were in Ankara (FRUS, 1960b, p.1236). In 1945 Turkish foreign policy went in the opposite direction from that proposed by Aras as Turkey swiftly entered the orbit of the new U.S.- and Britain-led Western alliance. Official historiography cites the USSR's "demands" for territory in eastern Anatolia and for military bases on the Straits as the reason for Turkey's pro-Western 
shift. Accordingly, it will be useful to take a closer look at the state of Soviet-Turkish relations in 1945.

\section{THE MOLOTOV-SARPER TALKS:}

\section{THE INVENTION OF SOVIET “DEMANDS"}

On March 19, 1945, Soviet Foreign Minister Molotov had a meeting with Turkey's ambassador to the USSR, Selim Sarper, informing him that Moscow would revoke the Turkish-Soviet Treaty of Friendship and Neutrality which had been in force since 1925. Molotov explained that fundamental changes had taken place during WWII and that the treaty was no longer suited to the new realities. In order for the treaty to be renewed, Molotov said it would have to be reviewed in light of the changed circumstances. On April 4, 1945, Ankara replied with a memorandum declaring its readiness to discuss the Soviets' proposal regarding the signing of a new treaty. The following month, on May 21, Sarper met with Soviet Ambassador Sergei Vinogradov in Ankara, where they discussed the possibility of the two countries forming an "alliance" (Turkish Foreign Policy, 1973, pp.256, 262). Two days later, on May 23, Prime Minister Saraçoğlu provided Sarper, who was about to return to Moscow, with written instructions which said: "The Republican government is inclined, as a matter of principle, to go as far as enacting a treaty of alliance with the Soviets." Molotov and Sarper had two face-to-face meetings in Moscow, on June 7 and June 18. Molotov stated that signing a treaty of alliance would depend on Turkey's decision regarding two points in the Soviet proposal: 1) the USSR's receiving the region of Kars and Ardahan, which had been granted to Turkey through the 1921 Treaty of Kars; and 2) the USSR's receiving military bases on the Straits. If Turkey rejected both these points, then the USSR would not sign such a treaty. In Molotov's view, if the two powers were unable to reach an agreement concerning an alliance, then they could still cooperate with each other to change the terms of the Montreux Convention regarding the Straits. In short, signing a treaty of alliance was conditional on Ankara's acceptance of Moscow's proposal. If Ankara said no, then Moscow would not sign a treaty, but could work together with Turkey to change the Montreux Convention. Sarper 
sent a report to Ankara, to which he appended his personal opinion, namely, he "had not thought the Soviets would cut the talks short, had not guessed that they would insist on territorial changes, and, to be honest, had the feeling that Molotov had brought this up in order to wring concessions from us on other points.” According to Sarper, even if the Soviets appeared "insistent on acquiring peace-time bases on the Straits," what they really wanted was "a formula of their own choosing, with concrete guarantees such as joint defense of the Straits in order to protect the Black Sea in the event of a war" (Turkish Foreign Policy, 1973, p.266). Thus, none less than Sarper, who represented Turkey in these talks, was of the opinion that the USSR did not truly insist on acquiring Turkish territory and bases, but was merely raising the issue in order to negotiate joint defense of the Straits.

In July of 1945, a dossier regarding the Molotov-Sarper talks, prepared by the Turkish side, was read at Turkey's Embassy in London by a foreign affairs committee handling diplomatic relations. In a diary entry dated July 10, 1945, one of the committee members, Nihat Erim (2004, p.40), criticized Sarper as follows: "Upon reading the minutes of the talks in Russia, it has become clear to us that Selim Rauf Sarper behaved in an amateur fashion. In our meetings in Ankara with Russian Ambassador Vinogradov, in particular, [Sarper] gave the impression that we were afraid of the Russians and that we were ready to make a new treaty, a new alliance regardless of the cost. In short, we have encouraged the Russians to make exorbitant demands. Selim made the same mistake in his talks with Molotov in Moscow. Molotov used certain expressions, but he did not specifically mention bases on the Straits, or Ardahan and Kars on our eastern border. Selim was the first to use these words. When Molotov spoke of taking measures on the Straits to ensure the safety of Russia's 200 millionstrong population, Selim asked; 'Do you want bases, then?'; Molotov spoke of the 1914 border, Selim asked: 'Kars and Ardahan?' In this way he made Molotov's task easier."

At subsequent international summits, the Soviets reiterated the proposals they had made at the Molotov-Sarper talks, again stressing that these were preconditions for the alliance desired by Ankara. 
The day before the Potsdam Conference, held a month after the Molotov-Sarper talks, British and Soviet Foreign Ministers Eden and Molotov met to discuss the negotiations between the USSR and Turkey. Repeating that the proposal concerning Kars and Ardahan was a precondition for entering into an alliance, Molotov stated that if this region-which changed from a Soviet to a Turkish possession in 1921 - were returned to the USSR, it would be settled with Armenians who had emigrated from Anatolia (Hasanli, 2011, pp.92-93). In this connection, it should be noted that in 1945 the USSR was the first member of the international community to bring the Armenian issue to Turkey's attention, following the 1915 tragedy in Anatolia. A few months before the Armenian National Council, with the Kremlin's knowledge, had published a declaration, ahead of the San Francisco Conference, requesting that "the Armenian provinces of Turkey" be returned to Armenia (Hasanli, 2011, pp.71-72). Furthermore, prior to the Potsdam Conference, Arutinov, First Secretary of the Central Committee of Soviet Armenia, had informed Molotov and Stalin in writing that if Kars and Ardahan were given back to Armenia, Armenians who had emigrated from Anatolia and become part of the global diaspora would return to their homeland (Beytullayev, 2006, pp.143-144).

During the Potsdam Conference the Soviets' proposals were brought up again, with first Molotov and then Stalin emphasizing that they were necessary for signing a treaty of alliance. When Churchill raised the subject, Stalin first felt the need to clarify the matter of Kars and Ardahan: "He [Stalin] pointed out that this question of the restoration of frontiers would not have been brought up if the Turks had not brought up the question of an alliance. An alliance meant that they would defend the frontiers of Turkey, just as Turkey would defend the frontiers of the Soviet Union, but in the Soviet opinion the frontiers in the area mentioned were incorrect and they had told the Turks that if there was to be an alliance the frontiers had to be rectified. If this were not done the question of an alliance would be dropped. What was there to be afraid of?" As for the issue of the Straits, Stalin declared that Turkey held the USSR "by the throat and 
gave it no outlet," a situation which was unacceptable to Moscow (FRUS, 1960a, Vol. 2, pp.302-303). Previously during the conference, Churchill had also elaborated his views on the subject. According to Churchill, "These were not demands made by the Soviet Government on Turkey... the Turks had asked for an alliance and then Molotov had stated the conditions for such an alliance. He [Churchill] saw that if Turkey asked for an offensive and defensive alliance, this would be the occasion when the Soviets would say what improvement they wanted in the Turkish situation" (FRUS, 1960a, Vol. 2, pp.256-257). Thus, contrary to the prevailing view on Turkey's foreign policy, Moscow never demanded territory and military bases on the Straits from Ankara. These proposals were merely set as a precondition for the alliance requested by Turkey, a fact pointed out not only in the private talks between Molotov and Sarper but also during official meetings held by various diplomats and statesmen (and, later, in their memoirs). Long after Molotov had left politics, he conducted a series of interviews with poet and author Felix Chuev, in which he remarked: "Stalin wished to do everything legally, by means of the UN," explaining that Moscow was not thinking of using military force against Turkey at the time (Çuyev, 2010, pp.116-117).

On July 7, 1945, Turkey's Ambassador to Washington Hüseyin Baydur met with Joseph Grew, then acting Secretary of State. Grew's comments on the Sarper-Molotov talks, namely, that they were "a friendly exchange of views" and that "no concrete threats had been made," were not well received by the Turkish ambassador (FRUS, 1960a, Vol. 1, pp.1045). On April 4, 1946, Stalin met with U.S. Ambassador Bedell-Smith to whom he explained that "the Soviet Union had no intention of attacking Turkey, nor did this intention exist," but also that "Turkey, with a government unfriendly to Russia, was too weak to protect" the Straits (FRUS, 1969, p.736). In 1946, diplomats from countries with close ties with the USSR, such as Poland, Yugoslavia, and Bulgaria, noted that Moscow had no territorial demands and that the crux of the matter for the USSR was to prevent the Straits from being used against itself by its "enemies" in a war (Beytullayev, 2006, pp.198, 238). In his memoirs, the First Secretary of the Georgian Communist 
Party, Akaki Mgeladze, recounts a telephone conversation with Stalin: "When the army under my command entered Bulgaria, I phoned comrade Stalin and said that I could liberate Georgian lands on the territory of Turkey. He immediately reacted, saying it was impossible for political reasons. I was very anxious about this issue and hoped to persuade comrade Stalin. Temptation was too great. You know, the military have such a habit. I again phoned comrade Stalin, but he asked me to forget about this idea. This would be a political adventure. If he had agreed, I would have liberated these lands within twenty-four hours" (Hasanli, 2011, p.134).

The end of WWII in Europe, the establishment of the United Nations at the San Francisco Conference, the Potsdam Conference bringing together the leaders of the three victorious powers to discuss the future of Europe-all these were indications that a profound transformation in international relations was underway, one which directly affected Turkey, as well. In Ankara, both the İnönü government and its opponents inside and outside the CHP were aware of what these signs portended. Even as early as April 1945 politicians close to İnönü, such as Faik Ahmet Barutçu and Asım Us, voiced their concern that opposition figures within the CHP were in a "plot." Compounding the government's worries was the possibility that the intraparty opposition might be joined by prominent politicians from the Atatürk era such as Tevfik Rüştü Aras, who was not a member of parliament (Koçak, 2009, pp.150-151). This opposition within the CHP came into the open on June 7, 1945, when four politicians campaigning against land reform and demanding democratic change, Celal Bayar, Fuat Köprülü, Adnan Menderes, and Refik Koraltan, presented a motion, known as the "Motion of the Four," to their parliamentary group. It was not accidental that the Motion of the Four occurred on June 7, the first day of the Sarper-Molotov talks, which would soon create havoc in the foreign policy of the İnönü government. Nonetheless, for the remainder of 1945 Ankara sought to link the developments in Turkey's internal and external affairs, viewing the emergence of an internal oppositionand the process by which this movement led to the founding of the Democrat Party-as inseparable from foreign policy. 
Towards the end of June, after details of the Sarper-Molotov talks were featured in the European press, CHP deputy Hüseyin Cahit Yalçın wrote in the newspaper Tanin: "We are faced with a Bolshevik threat. It threatens both us and Britain, and thus the entire world" (Yalçın, 1945a). In response, opposition journalist Zekeriya Sertel, in a piece for Tan, described post-war Russia as "having promised that it would not seek any kind of territorial expansion" and as "having sworn to comply with all nations' rights of sovereignty and [territorial] integrity"; the notion that Russia would now demand territory and bases from Turkey was "inconceivable" (Sertel, 1945a). In Sertel's opinion, some evidently wished to create the impression that Turkey was the fuse that would ignite World War Three even if there were no real grounds for it. Two weeks later, Sertel elaborated his views somewhat further, writing that if the USSR "had shown any inclination to infringe on Turkey's territorial integrity and sovereignty right" it would find the entire world opposed to it (Sertel, 1945b). According to Sertel, if such rumors were mere hearsay, then the Turkish government had a responsibility to shed light on the matter, not to remain silent. Corroborating Sertel's statements, Cumhuriyet (1945a), relying on information from the Reuters news agency, ran headlines proclaiming that "The Russians have not issued a formal declaration" and "the matter has remained as an exchange of views between the Turkish and Russian delegates." However, CHP deputy Necmettin Sadak, who would serve as foreign minister between 1947 and 1950, accused Sertel and other opposition voices of "being unaware of the peril we currently face, or taking advantage of it" (Sadak, 1945). In response to Sertel's charge that the government was keeping society ignorant, Sadak wrote: “The Turkish nation, like everyone else, has learned all the facts. When the time comes, it will hear them from the government too."

Although pro-government journalists and politicians led the public to believe that Turkey was in a "dire" situation, two meetings held by President İnönü-first with high-ranking military officials in the Hadımköy district of Istanbul on July 8, 1945, and then with government bureaucrats the next day at Dolmabahçe Palace-painted a starkly different picture. A transcript of İnönü's statements at these 
meetings, published in 2003, sheds invaluable light on the Turkish government's true state of mind at the time. At each meeting, İnönü provided a detailed account of the Molotov-Sarper talks. He first stated that Turkey "had considered a far-reaching agreement" with the USSR, "even a treaty of alliance," adding that Molotov had said: "Before we can do that, we should iron out the issues between us." Inönü then listed the Soviets' proposals: “They said: 'First, we should revise the 1921 Treaty of Kars. This treaty was enacted at a time when the Soviet state was weak. We were therefore compelled to cede territory to you. Armenia suffered much injustice. The provinces which we allowed you to annex and which used to be Russian possessions must be returned... Second, if we are attacked via the Black Sea by an outside power, we need to ensure our security even in peacetime. And there needs to be a formal agreement about this right away. We said: '[In such a situation] we will close off the Straits, as we did in this war.' In response, they once more hemmed and hawed about how 'this needs to be done now.' We asked: 'What are these measures and steps [you are requesting]? Do you want bases?' They said: 'Something like that.' Then they said: 'Third, the Montreux Convention needs to be changed"' (Turan, 2003, pp.34-46).

After giving a summary of the Molotov-Sarper talks, İnönü stated: "The army we face is a mobilized one. It lies right before us in Bulgaria and in the Caucasus. In case the Russians promptly wage a campaign, we have even considered partial mobilization in order to protect ourselves against this outcome and in order not to be caught off guard in political negotiations. And we have studied how to do this in detail. We said: 'If we take things to the military preparation stage, we will precipitate the matter.' The situation is not so dire. It is preferable to act cautiously" (Turan, 2003, pp.34-46).

Given İnönü's assessment that the situation was not "dire," one wonders why Turkish newspapers, for days afterwards, acted as though the country was in great danger. İnönü did not believe that the USSR would resort to military force in order to make Turkey accept its proposals. He justified his opinion as follows: "Not long ago, in San Francisco, fifty nations signed a declaration that they would respect each other's territorial sovereignty. To take a step like this so soon afterwards 
would be to defy all of world opinion... there is little chance that the Russians would seek out a new adventure after all the sufferings they have endured." What did the USSR have in mind, then? In Inönü's words, "the really crucial issue is whether, under pressure, they [the Russians] can break up this country without a single shot being fired. In some circles it is said: 'In this country we need to have good relations and a policy of friendship with the Russians.' In recent times, perhaps the notion that our administration is weak has given them [the Russians] hope under these circumstances" (Turan, 2003, pp.34-46).

In alluding to the writings of Tevfik Rüştü Aras, İnönü clearly believed that the USSR intended to use the growing chorus of opposition in Turkey for its own ends and that it wished to provoke internal strife within Turkish society. At the same time, however, he was aware that within the newly emerging global order, Turkey could no longer delay its transition to a multi-party democracy: "My experience has led me to conclude that there is a need for opposition party in politics. But there is no point in creating one artificially. Any opposition party established today will be a communist party. The danger is that it will be the tool of a foreign state. As long as this can be prevented, there are advantages to having an opposition party." Thus, where the political opposition was concerned, İnönü signaled his readiness for transition to a multi-party system, declaring, "I will sponsor such a party in Parliament too." However, due to his concerns that any newlycreated opposition party would be communist and would fall under the sway of the USSR, he stressed that this party could only be created with his own sponsorship: "But only on condition that the party, at its core, have no ties to a foreign state; for them to establish an organization that answers to the Russians is unacceptable" (Turan, 2003, pp.34-46).

Towards the end of his speech at the July 9 meeting in Dolmabahçe Palace, İnönü once more pointed out that the Molotov-Sarper talks had not led to any official agreement: "Molotov and the Turkish ambassador spoke about every issue between the two states, but the Russian government did not take any formal steps. It was written that the Russians had issued a declaration; however, the Russian ambassador went to the Ministry of Foreign Affairs and repudiated this assertion... 
we should be aware that we must treat this merely as a proposal.” Thus, contrary to official historiography about the 1945 crisis, even President İnönü, a person occupying the highest position, stated that the USSR had not made a demand but rather a "proposal," one which had not led to any "formal steps" (Turan, 2003, pp.34-46).

The İnönü government was well aware that an Allied victory would lead to Turkey's isolation on the world stage due to the friendly relations Ankara had established with Germany during the war. As the Nazi Germany began to advance on the Caucasian Front, Moscow became seriously concerned that Ankara would join the war on the opposing side. Moreover, it had not escaped Moscow's notice that Ankara had turned a blind eye to the printing, from 1942 onwards, of pan-Turkist publications in Turkey aimed at Turkic minorities in the USSR (Ulunian, 2003, pp.36-38). Stalin and Molotov believed they would not be able to count on the neutrality of Turkey, which was located just to the south of the Caucasian Front (Roberts, 2011, p.70). It was Ankara which took the first steps towards alleviating the USSR's concerns vis-à-vis Turkey in 1944, when the Red Army won numerous victories against Nazi Germany. Starting in May 1944, there were mass arrests of Nazi sympathizers along with prominent members of various anti-communist, nationalist extremist and racist groups. On May 23, 1945, Prime Minister Saraçoğlu gave written instructions to Sarper to hold talks in Ankara about an alliance with the USSR. Just a few weeks before, in the May 11 speech to parliament, Saraçoğlu had effusively praised Stalin, calling him a "genius": "The Soviets have written many illustrious pages of this world war, and Stalin's robust face can always be seen on every single page" (TBMM, n.d., p.45). Despite all these praises, Ankara did not receive a very promising answer from Moscow to its offer of an alliance. All the same, it regarded Moscow's suggested preconditions for an alliance (territorial changes and military bases on the Straits) not as threats but as a bargaining strategy. Yet Ankara lost no time capitalizing on these developments in order to strengthen its own hand. The İnönü government foresaw that it would not be long before the Allied partnership-based on opposition to Hitler-would soon 
give way to a Cold War. Ankara believed that by creating the myth of the "threat" of communism and Soviet "expansionism" it could bring about a rapprochement with the West and end its own isolation. Ankara knew that its best trump card in such a Cold War was the geopolitical importance of Turkey situated at the southern border of the USSR and controlling the Straits. And indeed, Turkey's critical geopolitical location vis-à-vis the USSR, along with what Leffler has described as a "fear of Turkey's neutrality" (1985, p.823), was a key determinant of American foreign policy-makers' stance on Ankara.

From 1945 onwards, the ideological construct of Soviet "expansionism" and a communist "threat" would provide Ankara with a useful tool for manufacturing a political opposition in Turkey's inevitable transition to a multi-party democracy. According to Hakan Yllmaz, in the İnönü government's shift to a multi-party system, there was a purge of opposition groups which favored close ties with the USSR and therefore constituted an alternative to the existing regime (Yllmaz, 1997, p.5). At the same time, when it came to foreign policy, the İnönü government was acting on predictions that the circumstances of the Cold War would allow it to establish close ties with the U.S. Essentially, a "national psychosis" which had afflicted Ankara since the start of WWII-one which Hugessen, Britain's ambassador to Turkey, candidly described as an "insane Russian complex"-was effective in stoking the İnönü government's fear that opposition groups within Turkey would be used by the Kremlin to Turkey's detriment (Tamkin, 2009, p.116). Consequently, the idea of Soviet "expansionism" and the communist "threat" was the most important tool used by the İnönü government, which wanted to achieve a rapprochement with the West and which sought to keep the political opposition under its control in the inevitably emerging multi-party political system.

\section{REINING IN THE OPPOSITION}

The fall of 1945 witnessed significant changes in Turkish politics, ones which came to a head with the founding of the Democrat Party on January 7, 1946. First, on September 21, Fuat Köprülü and Adnan Menderes were purged from the CHP, followed by Refik Koraltan on 
December 22. Celal Bayar resigned from the CHP on December 3. During the same period, Tan columnists Zekeriya Sertel, Sabiha Sertel, and Tevfik Rüştü Aras attempted to set up a democratic front in Turkey, coming eventually into close contact with politicians ousted from the CHP. Tan was known for its criticism of the government's policy towards the USSR. Indeed, in the spring of 1945, Faik Ahmet Barutçu, one of İnönü's closest associates, offered the following assessment of Bayar, Aras, and Fevzi Çakmak in his diary: "Are these men thinking of waiting in the wings as statesmen who will promote a policy of a Russian-Turkish alliance, contrary to the Government's policy of a British-Turkish alliance? Do they all share that idea? We must wait and see how things turn out rather than pass judgment!” (Barutçu, 1977, pp.282-283).

In December 1945, the ruling party passed its "judgement" on the opposition and carried it out, with youths in Istanbul gathering en masse (with governmental assistance) and raiding the offices of Tan. This served both to delegitimize the left-wing opposition-portrayed as cooperating with the USSR, which had "demanded" territory from Turkey-and to prevent the emergence of political opposition in the form of a democratic front. Cemil Koçak described the raid on the printing press of Tan as "a script whose mise en scène and results had been planned in advance" by the government. According to Koçak, the ruling party preferred to use mob "violence" to stifle the left-wing opposition rather than the traditional methods of shutting down the newspaper and sentencing people to prison (2009, pp.796-811). In doing so, the Turkish government was presenting itself to the U.S. as a country which was "hindering internal communist aggression." The turning point in the events that led to the raid on Tan occurred with the December 1, 1945 issue of the journal Görüşler. Its cover featured pictures of prominent members of the circle known as the "democratic front” (Celal Bayar, Tevfik Rüştü Aras, Fuat Köprülü, Adnan Menderes, Cami Baykurt, and Sabiha Sertel) with the caption "Those who have pledged to support our journal by writing columns." In the journal's first issue, Zekeriya Sertel wrote: "The outlook based on the elections held so far is that nations are tilting to the left" (1945c), while Sabiha 
Sertel, in her column entitled "Zincirli Hürriyet" (Freedom in Chains), announced that the group's objective was "the struggle to create a new Turkey” (Sertel, 1945). On December 3, 1945, CHP deputy and Tanin Editor-in-Chief Hüseyin Cahit Yalçın responded to Sertel with his column entitled-in a reference to Namık Kemal- "Kalkın Ey Ehli Vatan! Bir Vatan Cephesine Lüzum Vardır" (Arise, O People of the Nation! A National Front is Needed): "When I opened Görüşler and read Ms. Sertel's column, 'Freedom in Chains,' I immediately understood what sort of freedom they are preparing for us with those bright red chains decorating the page... it is not up to the government to take action in this matter. Pen-wielding journalists-as well as free citizens-have the final say" (Yalçın, 1945b)

The vandalization of Tan's printing press (along with the ABC and Berrak bookstores-which sold Soviet publications-and the newspapers Yeni Dünya and La Turquie) by these "free citizens" to whom the government gave the "final say" was described approvingly in the Turkish press. There is little question that the ruling party regarded the democratic front which had sprung up in the fall of 1945 as a serious threat to its own survival, a sentiment which was evident in a remark made by President İnönü in a talk in Eskişehir on May 3, 1946: "There will be a merger between Tan and Vatan, they will spread their propaganda for three months, and then the entire nation will suddenly fall to pieces" (Turan, 2003, p.76). On December 4, 1945, the day of the raid on Tan, İnönü met with Celal Bayar, giving him the green light to find an opposition party, after receiving assurances from him on the issues of foreign policy and secularism.

In response to the raid on Tan, the USSR issued a declaration on December 8, stating: “Two bookstores selling Soviet publications have been wrecked and Soviet books have been destroyed." Referring to "the Turkish police, who protected the demonstration," it held the Turkish government responsible for the incidents (Cumhuriyet, 1945b). Some expressions used by the USSR's ambassador to Turkey, Sergei Vinogradov, immediately following the raid on Tan, and the response he received from Moscow make it clear that the USSR was unwilling to escalate the crisis. In his report to the Ministry of Foreign 
Affairs, Vinogradov recommended making a formal statement to Britain and the United States to the effect that "the fascist anti-Soviet demonstration in Istanbul may compel the Soviet Union to take adequate measures to ensure its security." He further recommended that the TASS news agency publish a story stating that "owing to the fascist anti-Soviet demonstration in Turkey, the Soviet government decided to reinforce garrisons along the Soviet-Turkish border" and urged the USSR to cut off all ties with Turkey. Moscow's response to Vinogradov made it quite clear that the USSR did not wish any escalation of tensions: "We consider your proposals to be absolutely unacceptable and thoughtless. You must understand that we cannot make any official presentations to the Turkish government regarding the growth of fascism in Turkey, since it is a domestic affair of Turkey. We also consider as inadmissible and not serious your proposal about our statement to British and Americans, since saber rattling may have provocative consequences. Your proposal on publishing TASS information that the Soviet government, due to the fascist antiSoviet demonstration in Turkey, decided to reinforce garrisons along the Soviet-Turkish border is too frivolous. Nor can we accept your proposal on discontinuing our contact with Turkey. You should not make thoughtless proposals that may lead to political complications for our government. Think of it once again and be more sober-minded to comply with your post and mission" (Hasanli, 2011, pp.152-153).

Although this internal correspondence from the Soviet archives shows that the USSR preferred to act circumspectly rather than escalate tensions, Moscow could not remain indifferent to these mass demonstrations in Turkey, which it viewed as anti-Soviet in nature, and which had been encouraged by the Turkish government. Accordingly, it took a different approach. On December 14, ten days after the raid on Tan, two Georgian academics wrote an article entitled "Our Legitimate Claims from Turkey," published first in the Georgian newspaper Kommunisti and then in Pravda and Izvestia. The Georgian academics demanded that Turkey return to Georgia the region encompassing "Ardahan, Artvin, Oltu, Tortum, İspir, Bayburt, Trabzon, and Gümüşhane," which they claimed historically 
belonged to Georgia (Canasia and Breredzenisvili, 1987, pp.4952). On December 21, and in the days that followed, the article made headlines in Turkish newspapers; the issue was also debated in parliament. A headline in the newspaper Ulus consisted of a sentence from Kazım Karabekir's speech to Parliament, "Whoever controls the plain of Kars is lying in wait to invade Anatolia," while the first page of Cumhuriyet printed a map of the region mentioned by the Georgian academics with the following caption: "The force of unchecked ambition: the territory which two Georgian professors wish to annex to Georgia" (Ulus, 1945; Cumhuriyet, 1945c). In the same news story, it was also reported that the Soviet newspapers had printed the academics' article without any comment and that official Soviet sources took no position on the region.

That same month, the USSR decided that all diaspora Armeniansincluding those living in Turkey-would be allowed to settle in Soviet Armenia from 1946 to 1949 (Hasanli, 2003, p.153). Reports of Armenians applying to go to Armenia at the Soviet Consulate in Istanbul were published on the front page of Turkish newspapers starting in mid-December, with disparaging captions such as "And yesterday 70 vagabonds applied to the Soviet Consulate" (Cumhuriyet, 1945d). According to Soviet sources, 1,500 Turkish citizens of Armenian ethnicity had applied to the Consulate in Istanbul for permission to return to Soviet Armenia. Staff at the Consulate took care to admit only one person inside at a time, with the express purpose of creating a long line in front of the building (Beytullayev, 2006, p.188). These measures taken by the USSR vis-à-vis the Armenian issue received a response from Turkey in a January 6, 1946 statement by Prime Minister Saraçoğlu: "Months ago, as you are aware, there were rumors and news stories in some newspapers and on some radio stations to the effect that 'the provinces of Kars and Ardahan should be given as a homeland to the Armenians who have migrated to various foreign countries.' The whole world knows that there is not a single Armenian in these places." Similarly, when a number of Armenian journalists told Saraçoğlu that "rumors [were] circulating among the Armenians in Istanbul... people are even saying that some Armenians 
will be subjected to forcible relocation," he replied: "Write that these rumors are completely without foundation: such a thing is impossible. People should get on with their work" (Cumhuriyet, 1946). Despite Soviet estimates that roughly 360,000-400,000 Armenians would return to Soviet Armenia, the total as of 1948 only amounted to 90,000 from 12 different countries (Hasanli, 2011, p.276).

From 1946 on, the subject of Kars and Ardahan ceased to be a real issue in Soviet-Turkish relations. In a diplomatic note dated August 7, 1946, the USSR informed the U.S., Britain, and Turkey of its demands via official channels, requesting that the Montreux Convention be changed to benefit the countries lying on the Black Sea coast, and that the Straits be protected through "cooperative measures" on the part of Turkey and the USSR. However, the U.S., Britain, and Turkey rejected these demands. Significantly, these official declarations made no mention of redrawing borders or the issue of territory, while alluding obliquely to the question of giving the Soviets military bases on the Bosporus.

\section{THE 1946 ELECTIONS AND THE GOVERNMENT'S USE OF THE “COMMUNIST THREAT"}

In the run-up to the 1946 elections, the ruling party and opposition began to debate Turkey's issues with the USSR. On April 29, 1946, Vatan printed an interview which Democrat Party Chairman Celal Bayar had given to an American newspaper. The headline in Vatan featured the following of Bayar's words: "Revolutionary Turkey and Soviet Russia have smoothed over all the differences that existed between the Ottoman Empire and Tsarist Russia." Declaring that "the rumors concerning Russia's demands are unfounded," Bayar argued that the political climate pro-government journalists were trying to foster, in which Turkey was in a state of crisis due to the Soviet threat, did not reflect reality (Vatan, 1946a). Bayar was inclined to view the issues discussed in the Molotov-Sarper talks as an off-the-record conversation or gossip rather than formal demands.

In his memoirs, Zekeriya Sertel describes a meeting at which Tevfik Rüştü Aras and Field Marshal Fevzi Çakmak took part. Çakmak, who 
stated that Turkey's recent difficulties with the USSR "did not require urgent action," is quoted as follows: "I cannot understand the supposed recent unease in Soviet-Turkish relations. Even Stalin's offer did not worry me. I believe we need to have dialogue with the Soviets. We should not take it amiss if they approach us with an inappropriate request. On the contrary, we should sit down with them and explain their errors to them. They are understanding people and have no malicious intentions towards us" (Sertel, 1977, p.269). Saffet Arıkan, who served as ambassador to Berlin between 1942 and 1944, was of the same opinion: "Russia is bluffing. This is a tentative move; if we are perceived as strong and decisive, their bluff will fall through. There is no reason to fear Russia militarily. The Russians are exhausted and lack strength" (Barutçu, 1977, p.287).

There was a unanimity of opinion that the USSR's proposals did not constitute a threat: this was the view of President İnönü, at the head of the government, his political opponents such as Bayar and Çakmak, and statesmen like Arıkan, none of whom found it credible that Moscow would compel Turkey to accept its proposals by the use of military force. Nonetheless, the pro-government press, especially prior to the July 21, 1946 general elections, exploited Turkey's disputes with the USSR to the hilt in order to undermine the political opposition. Shortly before the elections, Hüseyin Cahit Yalçın's newspaper Tanin applied unrelenting pressure on the opposition parties. Claiming that the USSR had demanded "our eastern provinces and the Straits," Yalçın asked the opposition: "Which Turks want to be on amicable terms with the Russians under such circumstances? O Democrat Party, are you those Turks?... Tell me, Democrat Party. Are you not one of us? Do you side with the Russians? Do you want to give Kars, Ardahan, Artvin, the Straits, and Istanbul to the Bolsheviks?" (Yalçın, 1946a) On July 18, just three days before the elections, Yalçın wrote another piece, with the title "Moscow Radio Supports the Democrat Party." In Yalçın's (1946b) words, "We have continued to speak frankly about the Democrat Party and its opinion regarding the greediness of Russia, which has designs on the Turkish nation. We have asked them, we have pressed them. We have received no answer. In such an important matter, they have sought 
a means of escape." On May 3, as pro-government newspapers were using foreign policy to force the opposition into a corner, President İnönü gave a talk to the people, in which he advised newly-formed parties of the importance of "not having relations with a foreign state, and being free of outside influences" as well as of "absolute unity in foreign policy." In İnönü’s words, "Setting out to conduct foreign policy by saying that we have no quarrel with Russia amounts to saying that is an insignificant matter and is not as important as we have made it out to be. There is an issue between Russia and ourselves, a very important one" (Turan, 2003, p.76). Behind closed doors, the government stressed that Turkey's issues with the USSR did not constitute a threat. However, it steadfastly persuaded the public that there was an ongoing crisis in foreign policy, due to which the ruling party needed to be supported while the opposition needed to fall in line. That the government used foreign policy as an electoral ploy against the opposition is further confirmed by a comment made by Fuat Köprülü, one of the founders of the Democrat Party, immediately following the elections: "If you want to know my personal opinion, I believe that the present foreign policy situation is not as dangerous as the government believes, or as it would have the nation believe in order to gain an electoral advantage" (Vatan, 1946b).

Turkey's disputes with the USSR in 1945, along with the claim that Moscow "demanded" Turkish territory and bases on the Straits, formed the backbone of Turkey's pro-Western foreign policy throughout the Cold War era. Prominent right-wing Turkish politician Mehmet Keçeciler's notes on the 1945 crisis are illuminating in this regard: “The Turkish right's perception of communism as a danger is not a phenomenon which arose in vain, for no purpose. During the Stalin era, the USSR's demanding Kars and Ardahan from Turkey, as well as bases on the Straits, compelled Turkey to join NATO; it also compelled Turkey to pass legislation banning the Communist Party and to pass Articles 141 and 142 of the Penal Code. It compelled Turkey to take special precautions against communism. And the Turkish right, 
since it has long been nationalist, had no choice but to adopt an anticommunist stance" (Çakır and Göktaş, 1991, p.70) Keçeciler's statement tellingly indicates what a dominant role allegations of Soviet "demands" played in Turkish politics and among the Turkish right. The struggle against communism - and by extension, against the Turkish left, which were seen as its off-shoot-was not primarily an ideological struggle; it was a struggle to prevent the country from being partitioned and to preserve its territory. Any view or policy which held the opposite was a threat which was to be eliminated.

The key point of this article is that the USSR never truly "demanded" bases or territories from Turkey. These issues arose as "proposals" from Moscow in response to Turkey's request for a treaty of alliance with the USSR. That these were "proposals" and not "demands" was made explicit not only in the Molotov-Sarper talks, but by Stalin and other top-ranking Soviet officials at international conferences. Many politicians from both the ruling party—not least İnönü-and the opposition pointed out that no formal "demands" had been made, but that these topics were merely addressed in bilateral talks. Moreover, Ankara did not think it very likely that the USSR-in the immediate aftermath of WWII, which had inflicted great destruction upon Europe and caused the deaths of millions-would demand territory and bases from Turkey by use of military force, against the wishes of the entire international community.

In 1945 the İnönü government became quite apprehensive of the challenge posed to its one-party rule-whether by CHP politicians such as Bayar, Menderes, Köprülü, and Koraltan, or by the left-wing opposition that sprang up around Tan-and of the possibility of a united democratic front. Speaking in Kars on May 15, 1946 and commenting on the USSR's behavior over the preceding year İnönü sought to connect recent events in foreign policy with internal developments: "If they [Russians] can create defeatism and dissent within-if they can win over Russian sympathizers in our country by setting up a bunch of organizations similar to the Tudeh Party in Iran, or rather those so-called Fatherland Front parties in Bulgaria and so on-then the rest will be easy for them. They had become so 
emboldened due to the influence they had acquired through their lengthy propaganda-they had become so emboldened due to the things said by those in Turkey who they imagine have given them information-that they made these proposals. But, before a week had passed, they saw that all those they had relied on were rotten to the core and that Turkey had come to its senses and risen up as one against a foreign threat" (Turan, 2003, p.113). By fabricating the "foreign threat" of which Inönü spoke, the Turkish government found a way to vet the opposition party and control internal politics in general.

In its construction of an external threat, the ruling party dwelled especially on the issue of the Soviets' territorial "demands"; it politically neutralized the left-wing opposition and left-wing newspapers by defining them as "fifth columnists" of Turkey's foreign enemy, the USSR, which it claimed wanted to partition the country. Silencing all voices of dissent and making society "come to its senses" and "unite" would undoubtedly ensure that the former CHP politicians who founded the opposition Democrat Party would remain in need of "sponsorship." In fact, İnönü counseled the Democrats as follows: “The negative effects of democracy arrive before its benefits do; first there is strife and increased violence. We must peacefully skip over this phase... Indeed, the British Labour Party waited a century to come to power. Forbear and wait ten years, at least: we will achieve this mentality in time, peacefully, and four years later we will test it once more" (Turan, 2003, p.80).

Not only were the Soviet "threat" and local "communist fifth columnists" brought to bear in order to "peacefully" skip over this period and purge unwanted political opposition; so was the "Armenian question." Given that scarcely thirty years had passed since the tragedy of 1915, with memories of that period still quite fresh, this was clearly a very effective political tactic. In his speech in Kars, right on the border with Soviet Armenia, İnönü was quick to reference history in describing Turkey's disputes with the Soviets: "The Armenian secret societies have been mobilized all over the world. Everywhere, exaggerated claims are made about the Armenians' former exploits, and they have started asking their allies to annex these lands to the Soviets" 
(Turan, 2003, p.110). With the inclusion of the "Armenian question," Turkey's 1945 crisis with the USSR became an entrenched foundational myth in Turkish foreign policy that lasted throughout the Cold War. Anyone taking a critical approach towards this myth and seeking to uncover what had really occurred in 1945 was branded as "communist" and silenced. Some remarks made by İnönü to Peyami Safa in 1946 can be understood as laying the groundwork for Turkey's internal policy, which throughout the Cold War was-and even today is-based on anti-communism and anti-leftism: "Communism will deprive us of our independent existence. We should stress this point at present in order to counter the communists' intense propaganda. A clash of doctrines is not very effective in rousing the masses. We should say striking things" (Erim, 2004, p.75).

What were these "striking things" which were employed "to rouse the masses"? They consisted of claims of "communist" fifth-columnists working with the USSR that had set its sights on Turkey's territory and Armenian secret societies-all with the aim of "partitioning" Turkey. Any attempts to challenge this discourse have proven fatal for the individuals in question.

\section{References}

Aras, T. R., 1945. Görüşlerim [My Views]. İstanbul: Semih Lütfi Kitabevi.

Barutçu, F. A., 1977. Siyasî Anılar [Political Memories]. İstanbul: Milliyet Yayınları.

Bennett, W. L., 1980. Myth, Ritual, and Political Control. Journal of Communication, 30(4), pp.166-179.

Berkes, N., 1997. Unutulan yıllar [Forgotten Years]. İstanbul: İletişim.

Beytullayev, E., 2006. Soviet Policy Towards Turkey, 1944-1946. PhD. University of Cambridge.

Bottici, C., 2007. A Philosophy of Political Myth. Cambridge University Press.

Canasia, S. and Breredzenisvili, N., 1987. Türkiye'den Haklı İstemlerimiz. [Our Justifiable Demands from Turkey]. Tarih ve Toplum, 46(8), pp. 49-52. 
Çakır, R. and Göktaş, H., 1991. Vatan, Millet, Pragmatizm: Türk Sağında İdeoloji ve Politika [Homeland, Nation, Pragmatism: Ideology and Politics of the Turkish Right]. İstanbul: Metis Yayınları.

Cumhuriyet, 1945a. Sovyet Talebleri [Soviet Demands]. Cumhuriyet, 01 July.

Cumhuriyet, 1945b. Türkiye ve Rusya arasında teati edilen notalar [The Notes Exchanged between Turkey and Russia]. Cumhuriyet, 16 December.

Cumhuriyet, 1945c. Soğuk Bir Şaka [A Cold Joke]. Cumhuriyet, 21 December.

Cumhuriyet, 1945d. Rusyaya Gitmek İsteyen İstanbullu Ermeniler [Armenians from Istanbul Wishing to Go to Russia]. Cumhuriyet, 15 December.

Cumhuriyet, 1946. Başbakanın Mühim Demeci [Prime Minister's Important Statement]. Cumhuriyet, 07 January.

Çuyev, F., 2010. Molotov Anlatıyor. Stalin’in Sağkolu ile Yapılan 140 Görüşme [Molotov Remembers. 140 Interviews with Stalin's Right-Hand Man]. İstanbul: Yordam Yayınları.

Della Sala, V., 2010. Political Myth, Mythology and the European Union. Journal of Common Market Studies, 48(1), pp.1-19.

Deringil, S., 2004. Turkish Foreign Policy During the Second World War: An 'Active' Neutrality. Cambridge: Cambridge University Press.

Dikerdem, M., 1980. Molotof'un Çağrısıyla Saraçoğlu’nun Gidişi Arasında Sovyet Politikasında Çok Şey Değişmişti [Much Had Changed in Soviet Politics between Molotov's Call and Saraçoğlu’s Departure]. Milliyet, 31 March.

Dikerdem, M., 1989. Hariciye Çarkı. [Foreign-Policy Wheel]. İstanbul: Cem Yayınevi.

Erim, N., 2004. Günlükler 1925-1979 [Diaries 1925-1979]. Vol. 1. İstanbul: Yap1 Kredi Yayınları.

FRUS, 1960a. Foreign Relations of the United States: Diplomatic Papers. The Conference of Berlin (The Potsdam Conference) 1945, Vol. 1-2. Washington, DC: U.S. Government Printing Office.

FRUS, 1960b. Foreign Relations of the United States: Diplomatic Papers. The Near East and Africa 1945, Vol. 8. Washington, DC: U.S. Government Printing Office.

FRUS, 1969. Foreign Relations of the United States, 1946, Eastern Europe, the Soviet Union, Vol. 6. Washington, DC: U.S. Government Printing Office. 
Hale, W., 2000. Turkish Foreign Policy Since 1774-2000. New York: Routledge.

Hasanli, J., 2011. Stalin and the Turkish Crisis of the Cold War, 1945-1953. Lanham: Lexington Books.

Küçük, Y., 1984. Türkiye Üzerine Tezler [Theses on Turkey]. Vol. 2. İstanbul: Tekin Yayınevi.

Koçak, C., 2009. İkinci Parti [Second Party], Vol. 1. İstanbul: İletişim Yayınları.

Leffler, M. P., 1985. Strategy, Diplomacy, and the Cold War: The United States, Turkey, and NATO, 1945-1952. The Journal of American History, 71(4), pp. 807-825.

Önder, Z., 2010. İkinci Dünya Savaşı̇nda Türk Dış Politikası [Turkish Foreign Policy during World War II]. Ankara: Bilgi Yayınevi.

Roberts, G., 2011. Moscow's Cold War on the Periphery: Soviet Policy in Greece, Iran, and Turkey, 1943-8. Journal of Contemporary History, 46(1), pp.58-81.

Sadak, N., 1945. Türkiye-Sovyet Rusya Münasebetleri Dolayısile Yanlış ve Şüpheli Görüşler [Turkish-Russia Relations: False and Questionable Opinions]. Akşam, 14 July.

Sertel, S., 1945. Zincirli Hürriyet [Freedom in Chains]. Görüşler.

Sertel, Z., 1945a. Türk Efkarının Aydınlığa İhtiyacı Vardır [Turkish Thoughts Need Light]. Tan, 28 June.

Sertel, Z., 1945b. Herkes Biliyor, Yalnız Türk Milleti Bilmiyor [Everyone Knows, Only the Turkish Nation Does Not Know]. Tan, 12 July.

Sertel, Z., 1945c. Haftanın Görüşleri [Views of the Week], Görüşler.

Sertel, Z., 1977. Hatırladıklarım [Memoirs]. İstanbul: Gözlem Yayınları.

Soysal, İ., 1965. Türkiye’nin Dış Münasebetleriyle İlgili Başlıca Siyası区 Andlaşmaları. [The Main Political Treaties Concerning Turkey's Foreign Relations]. Ankara: Türk Tarih Kurumu Basımevi.

Tamkin, N., 2009. Britain, Turkey and the Soviet Union, 1940-45: Strategy, Diplomacy and Intelligence in the Eastern Mediterranean. Basingstoke: Palgrave Macmillan.

Tan, 1939. Saraçoğlu Moskovaya Hareket Etti [Saraçoğlu Has Moved to Moscow]. Tan, 22 September.

TBMM, n.d. TBMM Tutanak Dergisi 1945, Vol. 17. 
Turan, İ., 2003. İsmet İnönü Konuşma, Demeç, Makale, Mesaj ve Söyleşiler [Ismet Inönü's Speeches, Statements, Articles, Messages and Interviews (1944-1950)]. Ankara: TBMM Kültür Sanat ve Yayın Kurulu.

Turkish Foreign Policy, 1973. Türkiye Dış Politikasında 50 Yll: İkinci Dünya Savaşı Yilları [Turkish Foreign Policy over the Last 50 Years after the Second World War]. Ankara: Dışişleri Bakanlığı Araştırma ve Siyaset Planlama Genel Müdürlügü.

Ulunian, A. A., 2003. Soviet Cold War Perceptions of Turkey and Greece, 194558. Cold War History, 3(2), pp.35-52.

Ulus, 1945. Kars Yaylasına Hakim Olmak Anadolu’yu İstila Etmek İçin Pusuya Yatmak Demektir, [To Dominate the Kars Plateau Means to Lie in Ambush to Invade Anatolia]. Ulus, 22 December.

Vatan, 1946a. İnkılap Türkiyesi ile S. Rusya, Osmanlı İmparatorluğu ile Çarlık Rusya Arasındaki Bütün Pürüzleri Ortadan Kaldırmışlardır [Revolutionary Turkey and Soviet Russia Have Smoothed Over All the Differences That Existed between the Ottoman Empire and Tsarist Russia."]. Vatan, 29 April.

Vatan, 1946b. Fuad Köprülü’nün Mühim Beyanatı [Important Declaration of Fuad Köprülü]. Vatan, 02 August.

Yalçın, H. C., 1945a. Üçüncü Dünya Harbi Tehlikesi Karşısında Türkiye [Turkey Facing the Danger of a Third World War]. Tanin, 27 June.

Yalçın, H. C., 1945b. Kalkın Ey Ehli Vatan [Rise Up, People of Homeland]. Tanin, 03 December.

Yalçın, H. C., 1946a. Bolşevikler Maskeyi Yüzlerinden Attılar [The Bolsheviks Threw Off Their Masks]. Tanin, 13 July.

Yalçın, H. C., 1946b. Moskova Radyosu Demokrat Partiyi Destekliyor [Moscow Radio Backs Up the Democrat Party]. Tanin, 18 July.

Yllmaz, H., 1997. Democratization from above in Response to the International Context: Turkey, 1945-1950. New Perspectives on Turkey, 17(Fall), pp.1-37.

Zaiotti, R., 2011. Performing Schengen: Myths, Rituals and the Making of European Territoriality Beyond Europe. Review of International Studies, 37(2), pp. 537-556. 